\title{
Surgical Treatment and outcome of TSH-producing pituitary adenoma
}

\section{Objective}

TSH-producing pituitary adenomas account for $1-2 \%$ of all pituitary tumors and there is debate wether transsphenoidal surgery or medical treatment should be recommended as first-line treatment. This study summarizes the authors surgical experience and puts it into context of literature concerning non-surgical treatment of TSHomas.

\section{Methods}

A retrospective analysis of 12 patients including imaging, laboratory testing, short-term and long-term parameters of remission and overall pituitary function.

\section{Results}

12 patients are presented, 3 are male, 9 are female, mean age is 40 years (16-56). Time from first symptoms to diagnosis was 92.5 months (12-180months).

Preoperative blood draws revealed mean TSH-levels of $8.07 \mathrm{mU} / \mathrm{l}$ (range $0.95-43.65$, SD 11.5), mean fT3 of $8.5 \mathrm{pmol} / \mathrm{l}$ (range 4.2 - 17.3, SD 3.2) and mean levels of fT4 of $25.7 \mathrm{pmol} / \mathrm{I}$ (range 18.7 - 33.1 SD 4.7). TSH-levels decreased to a mean of $0.69 \mathrm{mU} / \mathrm{I}$ (range $0.03-3.018$, SD 1) on postoperative day one and to $0.64 \mathrm{mU} / \mathrm{l}$ (range $0.01-3.5$, SD 1.1) between postoperative days 2 and 5 (table). Postoperative day 1 levels of fT3 and fT4 were measured at a mean of $3.68 \mathrm{pmol} / \mathrm{l}$ (range 2.3 - 5.7, SD 1.2) and 21.6pmol/l (range $15.5-28.5$, SD 4.1). A further decrease in fT3 and fT4 levels were observed during days 2 and 5 with fT3 reducing to a mean of $3.1 \mathrm{pmol} / \mathrm{I}$ (range 2-5.3, SD 0.98) and fT4 levels of $15.3 \mathrm{pmol} / \mathrm{l}$ (range $12.3-19.2$, SD 2) Data on long term development of TSH, fT3 and fT4 were available for 9 out of 12 patients, showing levels of mean TSH of $1.8 \mathrm{mU} / \mathrm{l}(0.39-4.45, \mathrm{SD} 1.16)$, mean levels of fT3 of $2.6 \mathrm{pmol} / \mathrm{l}(0.32-5$, SD 2.0) and mean levels of fT4 of $16.07 \mathrm{pmol} / \mathrm{l}$ (1.7 19.5, SD 2). ACTH and cortisol levels were available in 10 out of 12 patients showing mean ACTH-levels of $6.6 \mathrm{pmol} / \mathrm{l}(2.8-12.1, \mathrm{SD} 3.4)$ and mean cortisol levels of $356.8 \mathrm{nmol} / \mathrm{l}(158-893$, SD 216.8)

\section{Conclusion}

We argue that transsphenoidal surgery for TSHproducing adenoma of the pituitary should always be considered as the treatment of choice. Even in patients harboring invasive tumors or giant adenomas remission following surgery is highly probable. Postoperative hypopituitarism is very unlikely if patients are referred to centers with high case load of pituitary surgery.
Table 1 Demographic and Clinical Characteristics of all Patients

\begin{tabular}{|c|c|}
\hline \multicolumn{2}{|l|}{ Characteristic } \\
\hline \multicolumn{2}{|l|}{ Age-yr } \\
\hline median & 42 \\
\hline range & $16-56$ \\
\hline \multicolumn{2}{|l|}{ sex-no (\%) } \\
\hline male & $3(25)$ \\
\hline female & $9(75)$ \\
\hline \multicolumn{2}{|l|}{ recurrent disease-no (\%) } \\
\hline yes & 2(16) \\
\hline no & $10(84)$ \\
\hline \multicolumn{2}{|l|}{ History } \\
\hline \multicolumn{2}{|c|}{ time from first symptoms to surgery (months) } \\
\hline median & 72 \\
\hline range & $12-180$ \\
\hline Symptoms & patients - no \\
\hline tachycardia/palpations & 5 \\
\hline fatigue & 3 \\
\hline sweating & 3 \\
\hline$H / A$ & 1 \\
\hline infertility & 1 \\
\hline Diplopia/visual & 3 \\
\hline goiter & 3 \\
\hline \multicolumn{2}{|l|}{ MRI } \\
\hline median size $(\mathrm{mm})$ & $10 \times 10 \times 12$ \\
\hline range $(\mathrm{mm})$ & $4-20$ \\
\hline \multicolumn{2}{|l|}{ pretreatment } \\
\hline thyroid surgery & 1 \\
\hline Sandostatin & 3 \\
\hline Thiamazol & 4 \\
\hline Radioiod & 1 \\
\hline Bromocriptin & 1 \\
\hline L-TH & 2 \\
\hline Somatostatinanaloga & 1 \\
\hline
\end{tabular}
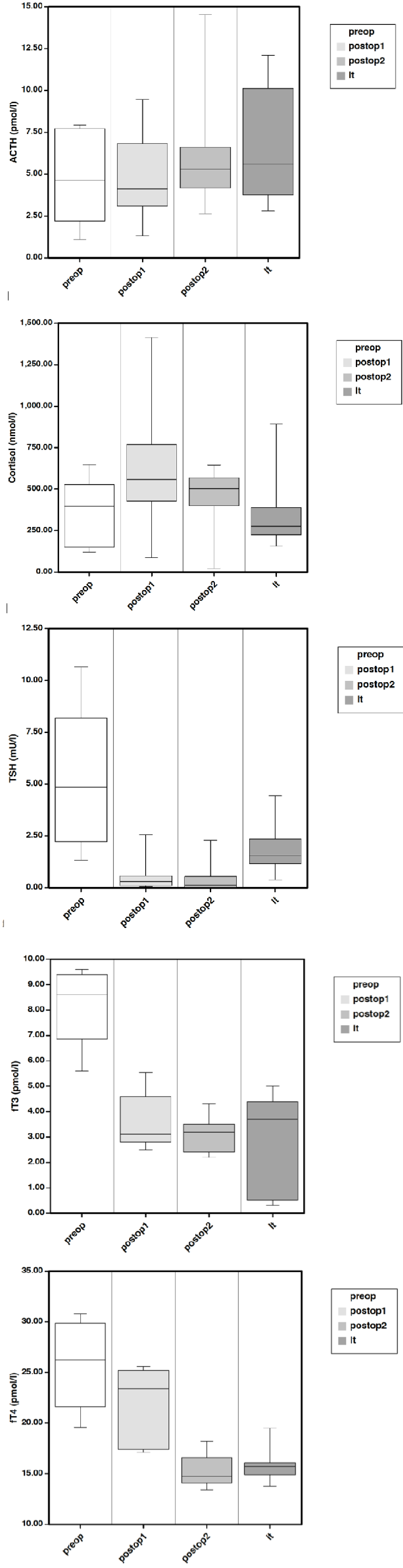